\title{
Review
}

\section{FISH PIGMENTATION AND THE MELANOCORTIN SYSTEM}

Laura Cal ${ }^{\mathrm{a}}$, Paula Suarez-Bregua ${ }^{\mathrm{a}}$, José Miguel Cerdá-Reverter ${ }^{\mathrm{b}}$, Ingo Braasch $^{\mathrm{c}} \delta$, Josep Rotllant $^{\mathrm{a} \delta}$ *

anstituto de Investigaciones Marinas, CSIC. Vigo, 36208, Spain. lauracal@iim.csic.es, paulasuarez@iim.csic.es, rotllant@iim.csic.es

${ }^{\mathrm{b}}$ Instituto de Acuicultura de Torre de La Sal, IATS/CSIC, Castellón, 12595, Spain. jm.cerda.reverter@csic.es

${ }^{c}$ Department of Integrative Biology and Program in Ecology, Evolutionary Biology and Behavior, Michigan State University, East Lansing, MI 48824, USA. braasch@msu.edu

${ }^{\delta}$ Co-senior authors

*Correspondence to: Josep Rotllant: rotllant@iim.csic.es. Aquatic Molecular Pathobiology Group. Institute of Marine Research (IIM). C/ Eduardo Cabello 6, 36208, Vigo. Spain. Phone: +34 986231930. Fax: +34 986292762

Funding: This work was supported by the Spanish Ministry of Economy and Competitiveness, project AGL2011-23581 


\section{ABSTRACT}

The melanocortin system is a complex neuroendocrine signaling mechanism involved in numerous physiological processes in vertebrates, including pigmentation, steroidogenesis and metabolic control. This review focuses at one of its most fascinating function in fish, its regulatory role in the control of pigmentation, in which the melanocortin 1 receptor $(\mathrm{Mc} 1 \mathrm{r})$, its agonist $\alpha$-melanocyte stimulating hormone $(\alpha-$ Msh), and the endogenous antagonist agouti signaling protein (Asip1) are the main players. Functional control of Mc1r, which is highly expressed in fish skin and whose activation stimulates melanin production and melanosome dispersion in fish melanophores, is considered a key mechanism for vertebrate pigment phenotypes. The $\alpha$-Msh peptide, the most documented Mc1r agonist involved in pigmentation, is produced in the pituitary gland, activating melanin synthesis by binding to Mc1r in fish melanophores. Finally, Asip1 is the putative factor for establishing the evolutionarily conserved dorso-ventral pigment pattern found across vertebrates. However, we are just starting to understand how other melanocortin system components are acting in this complex regulatory network.

Keywords: $\alpha$-Msh, Asip, Fish, Mc1r, Pigmentation, Pomc. 


\section{INTRODUCTION}

Pigment patterns exhibit a wide functional spectrum in vertebrates, including camouflage (Belk and Smith, 1996; Protas and Patel, 2008; Rudh and Qvarnström, 2013), thermoregulation (Ellis, 1980; Rudh and Qvarnström, 2013), photo-protection (Rudh and Qvarnström, 2013), mate choice (Kodric-Brown and Nicoletto, 2001; Bajer et al., 2011; Maan and Sefc, 2013), and others. Pigment patterns are primarily generated by the organized distribution of neural crest-derived pigment cells or chromatophores. Mammals have only one type of chromatophore - termed melanocytes - that produce both eumelanin, a melanin pigment that generates dark black, brown or grey colorations, and pheomelanin, a yellow to reddish melanin pigment. The ratio of pheomelanin to eumelanin production and the distribution of these pigment types in turn generate mammalian pigment patterns. In birds, probably the most diverse group of animals regarding melanin-based coloration, the integument (avian skin) also contains both eumelanin and pheomelanin (Galvan \& Solano, 2016).

However, the diversity and complexity of pigment patterns are exceedingly more complex in fish, which possess up to six different types of chromatophores with pigments of different chemical identities. Fish melanophores only produce eumelanin, but no pheomelanin (Fujii, 1993; Bagnara, 1998; Kottler et al., 2015), whereas xanthophores and erythrophores display pteridine and/or carotenoid pigments (Schartl et al., 2015). Iridophores and leucophores contain stacked crystalline platelets composed of purines, mainly of guanine, that are responsible for reflection of light (Fujii, 1993), while cyanophores contain blue pigmentary organelles of unknown chemical composition (Goda and Fujii, 1995; Schartl et al., 2015). The genetic basis of the chromatophore diversity in fish, particularly teleosts, remains poorly understood, but 
functional diversification of pigment pathway components following gene duplication in a teleost-specific genome duplication (TGD) event has been suggested as a potential contributing factor (Braasch et al., 2007, 2008, 2009a). Pigment patterns also depend on chromatophore interactions such as the striped pattern of the zebrafish (Danio rerio) (Maderspacher, 2003; Takahashi and Kondo, 2008; Patterson and Parichy, 2013; Singh et al., 2014; Eom et al., 2015). Zebrafish iridophores and melanophores show shortrange repulsion, which causes melanophore aggregation in the presence of iridophores, while iridophores and xanthophores exhibit mutual attraction, and xanthophores and melanophores repel each other (Frohnhöfer et al., 2013). Chromatophores in another teleost fish, the sole (Solea senegalensis), show similar cell type interactions to build a spotted pigment pattern (Darias et al., 2013).

In fish, most studies on pigment patterning have addressed teleost fishes, which represent around 96 percent of all living fish species and about half of all living vertebrates (Nelson 2006), and have focused on stripe formation using zebrafish as model system, identifying a core striping mechanism dependent on interactions between different pigment cell types. It has recently been demonstrated that zebrafish uses two distinct adult pigment patterning mechanisms: an ancient dorso-ventral patterning mechanism, which is present in all bony vertebrates and which is controlled by regulating melanin chemistry, pigment cell distribution, and development, and an evolutionary more recent striping mechanism based on the aforementioned pigment cell-cell interactions that provides zebrafish with its eponymous adult pattern of dark and light stripes. It has been determined that these two pigment patterning mechanisms function largely independently, with resultant patterns superimposed to generate the full, combinatory pattern (Ceinos et al., 2015). However, these pigment patterning 
mechanisms may change in response to different environmental stimuli, making it one of the most captivating features of fish pigmentation.

Fish color changes are accomplished by two different mechanisms: physiological and morphological color change. Physiological color change is caused by short-term stimuli and is based on pigment organelle aggregation or dispersion within skin chromatophores. Physiological color change is controlled by both sympathetic (noradrenalin) and endocrine ( $\alpha$-melanocyte stimulating hormone, $\alpha$-Msh, and melanin concentrating hormone, Mch) systems (Fujii, 2000). Noradrenalin and Mch released from chromaffin tissue and the pituitary have been shown to induce pigmentaggregation on light backgrounds (Kawauchi et al., 1983; Logan et al., 2006; Sugimoto, 2002). By contrast, $\alpha$-Msh induces pigment dispersion and its plasma level is increased on dark backgrounds (Logan et al., 2006; Mizusawa et al., 2013). Morphological color change, on the other hand, is caused by long-term stimuli and is mediated by apoptosis or proliferation of skin chromatophores, as well as changes in their cellular morphology. Several studies have demonstrated that fish also can morphologically change their color by decreasing or increasing the number and size of melanophores during long-term adaptation to light or dark background, respectively (Sugimoto et al., 2005; van der Salm et al., 2005). The opposite response, a decrease in dark backgrounds and increase in white backgorunds, is observed in the number of iridophores (Sugimoto et al., 2005). Both physiological and morphological color changes appear to be controlled by similar mechanisms, which at the molecular-cellular level include the melanocortin system.

The teleost fish melanocortin system consists of five melanocortin receptor subtypes (Mc1r, Mc2r, Mc3r, Mc4r, Mc5r), the endogenous agonists alpha and beta melanocyte stimulating hormone (Msh) and adrenocorticotropic hormone (Acth), melanocortin 
peptides derived from the proopiomelanocortin (pomc) gene, and the endogenous antagonists of the agouti signaling protein family (Asip1, Asip2, Agrp1 and Agrp2). All these components in their cellular context are illustrated in Fig. 1.

\section{MELANOCORTIN RECEPTORS}

The melanocortin system exerts its multiple functions via a number of G-protein coupled receptors (GPCRs), the melanocortin receptors (Mcrs). Within the GPCR family, Mcrs are included in the rhodopsin class, family A-13. To date, five Mcr types have been identified (Mc1r-Mc5r), differing in their spatial distribution, ligand affinities and specificities, thereby accomplishing a wide range of distinctive physiological role. A high degree of identity and conservation in structural characteristics and pharmacology exists between Mcrs from fish and mammals (Schiöth et al., 2005). In fish, at least five melanocortin receptors also mediate the diverse actions of melanocortins (Mc1r, Mc2r, Mc3r, Mc4r, Mc5r). In mammals, the Mc1r gene is mainly expressed in skin and is involved in coloration, while $M c 2 r$ is expressed in the adrenal gland and controls steroidogenesis. $M c 3 r$ and $M c 4 r$ are expressed in the brain and are involved in regulating the energy balance, and $M c 5 r$ is expressed in a number of different tissues and is involved in exocrine secretion (Cone, 2006; Cooray and Clark, 2011). In fish, the number, affinity, specificity, tissue distribution and the physiological roles are far from defined and appear to be species-specific. For example, pufferfish (Tetraodon nigroviridis) has only four receptors lacking Mc3r (Schiöth et al., 2005), while zebrafish has six receptors with two copies of Mc5r (Kumar et al., 2011). The larger number of Mcr paralogs found in some teleost species probably originated in the extra round of whole genome duplication that occurred during early teleost evolution 
(3R or TGD; Teleost Genome Duplication) (Braasch et al., 2008). In fish, mclr is expressed in the skin of the sea bass (Dicentrarchus labrax) and of the Mexican tetra cavefish (Astyanax mexicanus) and is also involved in pigmentation in cavefish (Gross et al., 2009; Sánchez et al., 2010); $m c 2 r$ is expressed in zebrafish (Danio rerio) interrenal tissue and controls cortisol synthesis (To et al., 2007); $m c 3 r$ is mainly expressed in the pufferfish (Takifugu rubripes) central nervous system (CNS) (Klovins et al., 2004b); $m c 4 r$ is also expressed in the sea bass CNS (Sánchez et al., 2009b) and in zebrafish peripheral tissues and is involved in food intake in sea bass and zebrafish (Cerdá-Reverter et al., 2003b; Forlano and Cone, 2007). Finally, $m c 5 r$ is expressed in different sea bass tissues and is involved in the regulation of hepatic lipid metabolism and, probably, pigmentation in sea bass (Sánchez et al., 2009a). Although $m c 5 r$ is duplicated in zebrafish, only one copy is present in most teleost genomes analyzed (Ringholm et al., 2002).

In mammals, the melanocortin-1 receptor (MC1R) is a key regulator of pigmentation. In both mammals and fish, the melanocortin-1 receptor (MC1R/Mc1r) is activated by $\alpha$ aMsh, which induces cAMP production (García-Borrón et al., 2005; Sánchez et al., 2010). In mammals, this cAMP increase activates - via protein kinase A (PKA) - the melanin synthesis pathway that involves the tyrosinase (TYR), tyrosinase-related protein 1 (TYRP1) and dopachrome tautomerase (DCT) enzymes, which ultimately results in de novo dark brown/black eumelanin pigment synthesis (Buscà and Ballotti, 2000; García-Borrón et al., 2005). This pathway is assumed to act very similar in teleosts, but the best-known effect of $\alpha-M s h-M c 1 r$ binding in fish is actually pigment dispersion within melanophores (Fujii, 2000). In fish and mammals, melanin is produced and deposited within specific organelles called melanosomes (Hearing, 2000). Interestingly, melanosomes are dispersed by the effect of $\alpha$-Msh also via a cAMP 
pathway in fish melanophores (Sugimoto et al., 1997; Logan et al., 2006; Kobayashi et al., 2009), which results in the skin darkening usually involved in physiological color change.

Sequence polymorphisms in the Mclr gene are associated with differences in pigmentation in amniotes (Valverde et al., 1995; Dun et al., 2007) and various mutations can result in an overactive MC1R, causing hyperpigmentation (melanism) in several mammalian and avian species (Robbins et al., 1993; Newton et al., 2000; Eizirik et al., 2003; Ling et al., 2003; Nadeau et al., 2006). Interestingly, a two base pair deletion $m c 1 r$ mutant apparently seems to cause hypopigmentation in some caveforms of the Mexican tetra Astyanax mexicanus (Gross et al., 2009).

The physiological function of Mclr can be antagonized by the paracrine signaling molecule protein agouti (Asip), which in amniotes is responsible for the switch to the production of the yellowish red pheomelanin pigments (Cone et al., 1996) and in fish for the inhibition of melanosome dispersion (Cerdá-Reverter et al., 2005). It is widely accepted that fish only synthesize eumelanin, while, to date, pheomelanin has not been identified in fish (Adachi et al., 2005; Braasch et al., 2009; Kottler et al., 2015). As in mammals, melanocortin 1 receptor (Mc1r) is encoded by a single-exon gene in fish and is present as a single gene with no known extra paralog even in teleost fish (Selz et al., 2007). The mclr gene encodes a protein with three intracellular loops, three extracellular loops and seven transmembrane helix domains (García-Borrón et al., 2005). It has been suggested that its C-terminus has an important role in coupling, transport and correct anchoring in the plasma membrane (Selz et al., 2007). Moreover, the intracellular phosphorylation sites are important for controlling Mc1r activity and numerous conserved sites have been identified among several vertebrate species (García-Borrón et al., 2005; Selz et al., 2007). The expression of $m c 1 r$ gene has been 
reported in the skin of most fish species studied so far: zebrafish (Danio rerio), medaka (Oryzias latipes), platyfish (Xiphophorus maculatus (Selz et al., 2007); cavefish (Astynax mexicanus) (Gross et al., 2009); barfin flounder (Verasper moseri) (Kobayashi et al., 2010); Japanese flounder (Paralichthys olivaceus) (Kobayashi et al., 2012a); goldfish (Carassius auratus) (Kobayashi et al., 2011b) and Japanese ornamental carp (Cyprinus carpio var. Koi) (Bar et al., 2013); and sea bass (Dicentrarchus labrax) (Sánchez et al., 2010). However, mclr expression is found in many other tissues and its expression levels vary among fish species (Klovins et al., 2004; Selz et al., 2007; Kobayashi et al., 2010; Sánchez et al., 2010; Takahashi et al., 2014).

In fish, $\alpha$-Msh and Acth affinities to Mc1r differ among species and depend on their acetylation level (Klovins et al., 2004; Kobayashi et al., 2010, 2012a; Sánchez et al., 2010). Interestingly, $m c l r$ expression has been reported in zebrafish, barfin and Japanese flounder melanophores (Kobayashi et al., 2010, 2012a; Higdon et al., 2013), in goldfish xanthophores (Kobayashi et al., 2011a) and in zebrafish iridophores (Higdon et al., 2013). Moreover, $m c l r$ is not the only melanocortin receptor gene expressed in fish chromatophores. The expression of $m c 5 r$ was also detected in melanophores and xanthophores in barfin flounder and Japanese flounder (Kobayashi et al., 2010, 2012b), and strong expression of $m c 5 r$ has been reported in the skin of goldfish (Cerdá-Reverter et al., 2003a) and sea bass (Sánchez et al., 2009a). Additionally, considering that Acth (a melanocortin agonist) may have a role in regulating fish pigmentation (Fujii, 2000) and that Acth acts on Mc2r (Aluru \& Vijayan, 2008) and low levels of $m c 2 r$ expression were detected in the skin of sea bass (Agulleiro et al., 2013), the involvement of Mc2r in fish pigmentation might be a possibility that merits study in more detail. 


\section{MELANOCORTIN AGONISTS}

Melanocortin receptors are stimulated by agonists, the melanocortins, a group of peptide hormones that include ACTH and different forms of MSH (Dores and Lecaude, 2005). Melanocortins are derived from post-translational cleavage of proopiomelanocortin (POMC) (Nakanishi et al., 1979) and are expressed mainly in corticotrope and melanotrope cells of the pituitary gland (Cerdá-Reverter and Canosa, 2009) (see Fig. 2). Comparisons of Pomc postranscriptional processing in several tissues showed that the precursor is cleaved in a tissue-specific (pituitary, skin, central nervous tissue and placenta) manner in both mammals and fish (Eberle, 2000; Cerdá-Reverter and Canosa, 2009; Takahashi and Mizusawa, 2013). The main enzymes cleaving POMC precursors are prohormone convertase 1 (PC1) and prohormone convertase 2 (PC2) (Bertagna, 1994). In corticotrope cells, PC1 cleaves POMC to produce ACTH and $\beta$-lipotrophin, but in the melanotrope cells the combined action of PC1 and PC2 cleave the precursor to produce $\alpha$-MSH and $\beta$-endorphin (Barr, 1991; Bertagna, 1994; Metz et al., 2006). After cleavage, POMC derived peptides are under the control of different modifications including acetylation and amidation, which modulate peptide activity and receptor binding (Wilkinson, 2006).

Acth is considered the main factor mediating the pituitary control of corticosteroid synthesis/secretion during fish stress response (Wendelaar-Bonga et al., 1994). Although it has been shown to mediate pituitary control of fish stress response (Wendelaar-Bonga et al., 1994), Msh is best known for the induction of melanosome dispersion in fish melanophores (Bagnara and Hadley, 1973). The precursor Pomc includes different Msh peptides, e.g., $\alpha$-melanocyte-stimulating hormone ( $\alpha$-Msh), $\beta$ - 
melanocyte-stimulating hormone $(\beta$-Msh) and $\gamma$-melanocyte-stimulating hormone $(\gamma$ Msh) (which has been lost in teleosts), all of which are characterized by a core HFRW sequence and localized in different domains of the precursor: $\gamma$-Msh in the $\mathrm{N}$-terminal pro- $\gamma$-Msh domain, $\alpha$-Msh in the Acth domain, and $\beta$-Msh in the C terminal $\beta$ lipotrophin domain (Barr, 1991; Bertagna, 1994; Metz et al., 2006) (Fig. 2).

$\alpha-\mathrm{MSH}$ induces the synthesis of the dark brown/black eumelanin pigment in vivo and in vitro cell culture disperses melanosomes by MC1R binding in vertebrates (Sugimoto et al., 1997; García-Borrón et al., 2005; Yamanome et al., 2007). In vitro experiments in mammals have shown that $\alpha$-MSH-MC1R binding leads to an increase of intracellular cAMP levels as a result of the stimulation of adenylyl cyclase (AC) (Kreiner et al. 1973). Additionally, high levels of intracellular cAMP activate protein kinase A (PKA) (Roesler et al. 1998) and induce the activation of tyrosinase enzyme mediated by the microphtalmia transcription factor (MITF) (Bertolotto et al. 1998). In vitro tests showed that tyrosinase is the essential and rate-limiting enzyme in melanin biosynthesis (Kobayashi et al. 1995). This is the classical pathway by which $\alpha$-MSH is mediating its melanogenic effects on melanocytes in mammals.

In fish, $\alpha$-Msh disperses melanosomes in both dermal and epidermal melanophores in vitro skin explants (Fujii and Miyashita, 1982) and stimulates melanophore proliferation and melanin synthesis in vivo (Fujii, 2000; Yamanome et al., 2007). A high degree of conservation of the melanin pathway has been reported among vertebrates (Hoekstra, 2006; Braasch et al., 2009). It seems that the melanogenic effect of $\alpha$-Msh is also mediated by binding to Mc1r. In vivo, $\alpha$-Msh stimulates Mc1r signal transduction, which is coupled to the activation of adenylyl cyclase, resulting in increased cytosolic levels of cAMP, which then activates PKA (Sugimoto et al., 1997; Sánchez et al., 2010). Moreover, teleost microphtalmia transcription factor a (mitfa) gene also has a 
conserved cAMP responsive element (CRE) region in its promoter region ( $\mathrm{Li}$ et al., 2013) and, like mammalian Mitf, induces melanization in vivo (Lister et al., 1999). In fish, in vitro experiments have also found that $\alpha$-Msh causes rapid melanosome dispersion within melanophores (Sugimoto et al., 1997; Logan et al., 2006; Kobayashi et al., 2009; Mizusawa et al., 2013). In vitro experiments showed that such melanosome dispersion is also regulated through activation of the cAMP pathway (Rozdzial and Haimo, 1986), and is dependent on extracellular $\mathrm{Ca}^{2+}$ ions (Fujii, 2000; Logan et al., 2006). The long-term effects of $\alpha$-Msh include melanophore proliferation and melanin synthesis in vivo (Yamanome et al., 2007), which is consistent with the $\alpha$-Msh effect in mammals. Therefore, it should also be noted that there are significant differences in the physiology of pigmentation between fish and mammals: the presence of different pigment cell types, the production of only eumelanin melanophores and the reversible dispersion and aggregation of melanosomes for rapid color change in fish. Moreover, it has been shown that in vitro Msh stimulates not only melanophores but also other types of chromatophores - xanthophores and iridophores (Matsumoto et al., 1977; Iga and Matsuno, 1986; Kobayashi et al., 2011a). In vitro, $\alpha$-Msh promotes xanthosome dispersion in xanthophores (Kobayashi et al., 2011a, 2012a) and may promote platelet aggregation in a specific type of iridophores (motile iridophores (Fujii, 2000)).

In fish, $\alpha$-Msh is involved in the process of physiological (short-term) (Mizusawa et al., 2013) and morphological (long-term) (Arends et al., 2000) background adaptation. The transfer of white-adapted fish to a black background results in the dispersion of melanophore pigment within a few hours (short-term) and increased plasma $\alpha$-Msh levels (Mizusawa et al., 2013). Although the role of $\alpha$-Msh in long-term background adaptation has been studied in several fish species (van Eys and Peters, 1981; Baker et al., 1984; Gilham and Baker, 1984; Rotllant et al., 2003; van der Salm et al., 2005; 
Mizusawa et al., 2013), no consensus regarding $\alpha$-Msh function regarding the specific types of background has emerged, which suggests multiple possible endocrine controls of background adaptation and/or a species-specific role for $\alpha$-Msh in long-term background adaptation.

A crucial factor that may determine $\alpha$-Msh melanogenic activity is the degree of acetylation at its N-terminal domain (Wilkinson, 2006; Takahashi and Mizusawa, 2013). Lower levels of monoacetyl- $\alpha-M s h$ have been found in sea bream adapted to a white compared to a black background (Arends et al., 2000). In tilapia (Oreochromis mossambicus), the greatest pigment dispersion was generated by monoacetyl- $\alpha$-Msh (van der Salm et al., 2005). By contrast, monoacetyl- $\alpha$-Msh had no effect on melanosome movements in barfin flounder and Japanese flounder, but did affect pigment dispersion in flounder xanthophores (Kobayashi et al., 2010, 2012b). In goldfish, both diacetyl- $\alpha$-and monoacetyl- $\alpha-\mathrm{MSH}$ stimulate pigment dispersion in xanthophores (Kobayashi et al., 2012a, 2012b). It therefore appears that there is no consistent response between $\alpha$-Msh acetylation levels and pigment dispersion among different fish species (Arends et al., 2000; Rotllant et al., 2003; van der Salm et al., 2005; Mizusawa et al., 2013). Additionally, recent in vitro pharmacological receptorbinding studies in Japanese flounder have shown that dimerization of Mc1r and Mc5r creates a ligand-dependent signal modulation (Kobayashi et al., 2106). The authors specifically showed that heterodimerization of Mc1r and Mc5r controls the inhibition of cAMP production in Japanese flounder melanophores as a result of $\alpha$-Msh but not deacetyl- $\alpha$-Msh activation.

\section{MELANOCORTIN ANTAGONISTS}


Another major feature of melanocortin receptors is the presence of endogenous antagonists that include agouti signaling protein (ASIP) and agouti-related protein (AGRP). ASIP is a paracrine signaling protein involved in mammalian pigmentation, which competes with $\alpha-\mathrm{MSH}$ by binding to MC1R and MC4R (Lu et al., 1994). AGRP is a neuropeptide involved in energy balance, body weight regulation and metabolism in mammals, acting as an antagonist of MC3R and MC4R in mammals (Ollmann et al., 1997). It has been extensively reported that ASIP regulates pigmentation in mammals (Lu et al., 1994; Siracusa, 1994; Norris and Whan, 2008; Fontanesi et al., 2012; Chandramohan et al., 2013). The Asip gene is composed of four exons that encode a 131 amino acid protein. This protein can be structurally divided into a $\mathrm{N}$-terminal basic domain that is rich in lysine $(\mathrm{K})$ residues, followed by a proline $(\mathrm{P})$-rich region localized just before the cysteine C-terminal domain (Bultman et al., 1992). The cysteine-rich Cterminus was identified as the key region for the competitive antagonism with MC1R (Ollmann and Barsh, 1999) and the C-terminal loop is the crucial domain for the inhibition of MC1R (Patel et al., 2010), while the amino-terminal residues are essential down-regulating MC1R (Ollmann and Barsh, 1999).

Asip is expressed in the mammalian dermal papillae of hair follicles (Millar et al., 1995) and promotes the switch from eumelanin (dark/brown pigment) to pheomelanin (yellow/red pigment) synthesis (Miller et al., 1993), acting as an $\alpha-\mathrm{MSH}$ competitive antagonist of the MC1 receptor (Ollmann et al., 1998). Additionally, studies in mouse have also reported an effect of ASIP on melanocyte differentiation and maturation (Manceau et al., 2011). Furthermore, dorsal-ventral variations in mouse hair coloration were shown to be due to different Asip expression levels (Manceau et al., 2011), and the expression of different ASIP isoforms in dorsal and ventral skin as result of the use of alternative promoters (Vrieling et al., 1994). 
In contrast to the two Agouti family genes in tetrapods (Asip and Agrp), the teleost agouti gene family is more complex, with four gene family members identified so far that were initially termed asip1, asip2, agrp, and agrp2 (Kurokawa et al., 2006) (Fig. S1). The connectivity of teleost to mammalian gene function depends on understanding gene orthologies and it has been suggested that asip2 and agrp2 are duplicates of asip/asipl and agrpl, respectively, resulting from teleost genome duplication (TGD) (Kurokawa et al., 2006). This interpretation of the evolutionary relationships of the four agouti family genes in teleosts, however, is controversial. Phylogenetic analyses alone are unlikely to resolve their evolutionary history (Braasch and Postlethwait, 2011; Schioth et al., 2011), and alternative data are needed.

A model based on the integration of conserved synteny data (Braasch and Postlethwait, 2011) proposes that the agrp/asip gene precursor was duplicated in the R1 and R2 rounds of vertebrate genome duplication and that Agrp2 and Asip2 went missing from tetrapods, while asip2 was retained in the lineage leading to teleosts. This asip2 gene was then further duplicated in the TGD, giving rise to the teleost genes that were initially called asip2 and agrp2 (Kurokawa et al., 2006), but which should be called asip2a and asip2b (Braasch and Postlethwait, 2011). According to this model, the second duplicates from the TGD of both asipl and agrpl were lost in teleosts, so that there is only one agrp type gene in teleosts, but three asip type genes (asip1, asip2a, asip2b) (Braasch and Postlethwait, 2011) (Fig. S1). While this conserved synteny-based model therefore suggests that the agouti gene repertoire is an outcome of the three rounds of vertebrate genome duplication (Braasch and Postlethwait, 2011), other studies favor a model of subsequent small scale gene duplications generating the agouti gene family (Schioth et al., 2011; Västermark et al., 2012). To resolve these differing views on the agouti gene family evolution, further analyses integrating data from the multitude 
of recent new vertebrate genome assemblies will be required. Of relevance for our discussion here is that there are three teleost genes with known functions for pigmentation patterning: asip1, asip2b (aka agrp2) and agrp1.

Dorso-ventral countershading in mammals is driven by the regulation of Asip expression and the resulting type of melanin synthesis (eu-/pheomelanin) in differentiated melanocytes. In fish, such dorso-ventral countershading is, in contrast, achieved by differences in the distribution of different types of pigment cells (Bagnara and Matsumoto, 2006). Despite these different countershading mechanisms in fish and in mammals, it has recently been shown that fish asipl shows a dorso-ventral expression gradient in the skin of several adult fish species with lower levels in the dorsum and high levels in the ventrum (Cerdá-Reverter et al., 2005; Kurokawa et al., 2006; Guillot et al., 2012; Agulleiro et al., 2014; Ceinos et al., 2015) (Fig. 2). This asipl expression gradient is not restricted to teleosts, but is also found in the non-teleost rayfinned fish spotted gar (Lepisosteus oculatus) (Cal et al., 2017; Fig. 3), which diverged from teleosts before the Teleost Genome Duplication (TGD) (Amores et al., 2011; Braasch et al., 2016). This expression pattern correlates with the dorso-ventral pigment pattern in gar showing darkly colored skin in the dorsal area and a light ventrum.

Additionally, it has also been shown that ectopic overexpression of asipl or injection of capped asipl mRNA induces lightening of dorsal skin in zebrafish (Ceinos et al., 2015) (See Fig. 4) and flatfish (Guillot et al., 2012) respectively. Moreover, asipl mRNA ectopic overexpression and injection in turbot (Scophthalmus maximus) results in reduced expression of tyrosinase-related protein-1 (tyrpl) gene, a key enzyme of melanin synthesis (Guillot et al., 2012; Ceinos et al., 2015). It should also be mentioned that Asip1 inhibits $\alpha$-Msh-induced melanosome movement on the scales of medaka (Oryzias latipes) via Mc1r (Cerdá-Reverter et al., 2005). All this evidence suggests that 
agouti (Asip1) has a conserved function in bony vertebrates for the overall dorso-ventral pigment pattern, but that it may act through different cellular mechanisms in mammals and ray-finned fish. Apart from the obvious role of Asip1 in fish pigmentation, it has been reported that zebrafish Asip2b/Agrp2, which is mainly expressed in the pineal gland and brain, antagonizes Mc1r. This melanocortin receptor is highly expressed in the zebrafish hypothalamus and up-regulates proMch (pmch) and proMch-like (pmchl) genes, which regulate background adaptation (Zhang et al., 2010). The agrp2/asip2b gene is also expressed in the skin of different teleost species like zebrafish (Zhang et al., 2010), sea bass (Agulleiro et al., 2014), Atlantic salmon (Salmo salar) (Murashita et al., 2009) and fugu (Takifugu rubripes) (Kurokawa et al., 2006). Another endogenous antagonist probably involved in pigmentation is Agrp1/Agrp, which has been reported to act as inverse agonist of Mc1r in sea bass, where it is thought to affect pigmentation (Sánchez et al., 2010). Histological studies have revealed that agrpl is expressed in the skin of fugu (Kurokawa et al., 2006), sea bass (Agulleiro et al., 2014), Atlantic salmon (Murashita et al., 2009) and goldfish (Cerdá-Reverter et al., 2003b). Despite the above evidence and the fact that induced stable overexpression of Agrp1/Agrp does not alter the zebrafish pigment pattern phenotype (Song and Cone, 2007), the role of Agrp1/Agrp in fish pigmentation remains to be fully explored.

\section{CONCLUSION AND FUTURE PERSPECTIVES}

Despite the identification of a variety of loci involved in pigmentation in several vertebrates, the melanocortin system is consistently found as a major determinant of vertebrate pigment phenotypes and patterns. In fish, the color pattern mechanisms involve a patterned distribution of different types of pigment cells or chromatophores. In fact, it has recently been demonstrated that two distinct adult pigment patterning 
mechanisms function in zebrafish - an evolutionary ancient dorso-ventral patterning mechanism, and an evolutionary more recent striping mechanism based on cell-cell interactions. These two mechanisms function largely independently, with the resultant patterns superimposed to give the full pattern. In fish as in mammals, the melanocortin system is also a key player in the establishment of the adult pigment pattern, with Mc1r, $\alpha \mathrm{Msh}$ and Asip1 each playing a fundamental role, suggesting an overall conserved function throughout vertebrate evolution. However, the possible role that other members of the melanocortin system may have on fish pigmentation needs to be further addressed. Although some light has been thrown on the regulation of fish pigmentation by the melanocortin system (Asip1, for example), much is still not clear. Therefore, future studies should focus on the response of each type of chromatophore to the melanocortin system, the possible involvement of other melanocortin agonists/antagonists and receptors in pigment pattern establishment, and the evolutionary conservation of these mechanisms in vertebrates. There is no doubt that we still have a long way to go before we fully understand how the melanocortin system modulates fish pigmentation and vertebrate color patterning in general.

\section{ACKNOWLEDGMENTS}

This work was funded by the Spanish Economy and Competitiveness Ministry project ALG2011-23581 and AGL2014-52473R to JR. Laura Cal was supported by Spanish Economy and Competitiveness Ministry FPI grant BES-2012-055414. Paula SuarezBregua was supported by a Campus do Mar PhD grant, Xunta de Galicia and AGL2014-52473R project contract. 


\section{REFERENCES}

Adachi, K., Kato, K., Wakamatsu, K., Ito, S., Ishimaru, K., Hirata, T., Murata, O., Kumai, H., 2005. The histological analysis, colorimetric evaluation, and chemical quantification of melanin content in "suntanned" fish. Pigment Cell Res. 18, 465468.

Agulleiro, M.J., Cortés, R., Leal, E., Ríos, D., Sánchez, E., Cerdá-Reverter, J.M., 2014. Characterization, tissue distribution and regulation by fasting of the agouti family of peptides in the sea bass (Dicentrarchus labrax). Gen. Comp. Endocrinol. 205, $251-259$.

Agulleiro, M.J., Sánchez, E., Leal, E., Cortés, R., Fernández-Durán, B., Guillot, R., Davis, P., Dores, R.M., Gallo-Payet, N., Cerdá-Reverter, J.M., 2013. Molecular characterization and functional regulation of melanocortin 2 receptor (MC2R) in the sea bass. A putative role in the adaptation to stress. PLoS One 8, e65450.

Aluru, N. \& Vijayan, M.M., 2008. Molecular characterization, tissue-specific expression, and regulation of melanocortin 2 receptor in rainbow trout. Endocrinology. 149, 4577-4588.

Amano, M. \& Takahashi, A., 2009. Melanin-concentrating hormone: A neuropeptide hormone affecting the relationship between photic environment and fish with special reference to background color and food intake regulation. Peptides. 30, 1979-1984.

Amores, A., Catchen, J., Ferrara, A., Fontenot, Q., Postlethwait, J., 2011. Genome evolution and meiotic maps by massively parallel DNA sequencing: spotted gar, an outgroup for the teleost genome duplication. Genetics. 188, 799-808. 
Arends, R.J., Rotllant, J., Metz, J.R., Mancera, J.M., Bonga, S.E.W., Flik, G., 2000. aMSH acetylation in the pituitary gland of the sea bream ( Sparus aurata L .) in response to different backgrounds, confinement and air exposure. J. Endocrinol. $166,427-435$.

Bagnara, J.T., 1998. Comparative anatomy and physiology of pigment cells in nonmammalian tissues, in: Nordland, J., Boissy, R., Hearing, V., King, R., Ortonne, J. (Eds.), The Pigmentary System. Physiology and Pathophysiology. Oxford University Press, New York, pp. 9-40.

Bagnara, J.T., Hadley, M.E., 1973. Chromatophores and Colour Change- The Comparative Physiology of Animal Pigmentation, Chromatophores and Colour Change. Englewood Cliffs, N.J., Prentice-Hall.

Bagnara, J.T., Matsumoto, J., 2006. Comparative anatomy and physiology of pigment cells in nonmammalian tissues, in: J. J. Nordlund, R. E. Boissy, V. J. Hearing, R. A. King, W. S. Oetting, \& J.-P.O. (Ed.), The Pigmentary System: Physiology and Pathophysiology. Blackwell Publishing, Oxford, pp. 11-59.

Bajer, K., Molnár, O., Török, J., Herczeg, G., 2011. Ultraviolet nuptial colour determines fight success in male European green lizards ( Lacerta viridis ). Biol. Lett. 7, 866-868.

Baker, B.I., Wilson, J.F., Bowley, T.J., 1984. Changes in pituitary and plasma levels of MSH in teleosts during physiological colour change. Gen. Comp. Endocrinol. 55, $142-149$.

Bar, I., Kaddar. E., Velan, A., David, L., 2013. Melanocortin receptor 1 and black pigmentation in the Japanese ornamental carp (Cyprinus carpio var. Koi) Front 
Genet. 2013; 4-6.

Barr, P.J., 1991. Mammalian Subtilisins : The Long-Sought Dibasic Processing Endoproteases Minireview. Cell 66, 1-3.

Belk, M.C., Smith, M.H., 1996. Pelage coloration in oldfield mice (Peromyscus polionotus): Antipredator adaptation? J. Mammal. 77, 882-890.

Bertagna, X., 1994. Proopiomelanocortin-derived peptides. Endocrinol. Metab. Clin. North Am. 23, 467-485.

Bertolotto, C., Buscà, R., Abbe, P., Bille, K., Aberdam, E., Ortonne, J.P., Ballotti, R., 1998. Different cis-acting elements are involved in the regulation of TRP1 and TRP2 promoter activities by cyclic AMP: pivotal role of M boxes (GTCATGTGCT) and of microphthalmia. Mol. Cell. Biol. 18, 694-702.

Braasch, I., Brunet, F., Volff, J.-N., Schartl, M., 2009a. Pigmentation pathway evolution after whole-genome duplication in fish. Genome Biol. Evol. 1, 479-493.

Braasch, I., Gehrke, A.R., Smith, J.J., Kawasaki, K., Manousaki, T., Pasquier, J., Amores, A., Desvignes, T., Batzel, P., Catchen, J., Berlin, A.M., Campbell, M.S., Barrell, D., Martin, K.J., Mulley, J.F., Ravi, V., Lee, A.P., Nakamura, T., Chalopin, D., Fan, S., Wcisel, D., Cañestro, C., Sydes, J., Beaudry, F.E.G., Sun, Y., Hertel, J., Beam, M.J., Fasold, M., Ishiyama, M., Johnson, J., Kehr, S., Lara, M., Letaw, J.H., Litman, G.W., Litman, R.T., Mikami, M., Ota, T., Saha, N.R., Williams, L., Stadler, P.F., Wang, H., Taylor, J.S., Fontenot, Q., Ferrara, A., Searle, S.M.J., Aken, B., Yandell, M., Schneider, I., Yoder, J.A., Volff, J.-N., Meyer, A., Amemiya, C.T., Venkatesh, B., Holland, P.W.H., Guiguen, Y., Bobe, J., Shubin, N.H., Di Palma, F., Alföldi, J., Lindblad-Toh, K., Postlethwait, J.H., 2016. The 
spotted gar genome illuminates vertebrate evolution and facilitates human-teleost comparisons. Nat. Genet. 48, 427-437.

Braasch, I., Liedtke, D., Volff, J.-N., Schartl, M., 2009b. Pigmentary function and evolution of tyrp1 gene duplicates in fish. Pigment Cell Melanoma Res. 22, 839850.

Braasch, I., Postlethwait, J.H., 2011. The teleost agouti-related protein 2 gene is an ohnolog gone missing from the tetrapod genome. Proc. Natl. Acad. Sci. U. S. A. 108, E47-48.

Braasch, I., Schartl, M., Volff, J.-N., 2007. Evolution of pigment synthesis pathways by gene and genome duplication in fish. BMC Evol. Biol. 7, 74.

Braasch, I., Volff, J.-N., Schartl, M., 2008. The evolution of teleost pigmentation and the fish-specific genome duplication. J. Fish Biol. 73, 1891-1918.

Bultman, S.J., Michaud, E.J., Woychik, R.P., 1992. Molecular characterization of the mouse agouti locus. Cell 71, 1195-1204.

Buscà, R., Ballotti, R., 2000. Cyclic AMP a key messenger in the regulation of skin pigmentation. Pigment Cell Res. 13, 60-69.

Cal L, Megías M, Cerdá-Reverter JM, Postlethwait JH, Braasch I, Rotllant J. 2017.

BAC Recombineering of the Agouti Loci from Spotted Gar and Zebrafish Reveals the Evolutionary Ancestry of Dorsal-Ventral Pigment Asymmetry in Fish. J Exp Zool B Mol Dev Evol. 2017 May 24. doi: 10.1002/jez.b.22748.

Ceinos, R.M., Guillot, R., Kelsh, R.N., Cerdá-Reverter, J.M., Rotllant, J., 2015. Pigment patterns in adult fish result from superimposition of two largely 
independent pigmentation mechanisms. Pigment Cell Melanoma Res. 28, 196-209.

Cerdá-Reverter, J.M., Canosa, L.F., 2009. Neuroendocrine Systems of the Fish Brain, in: Bernier, N.J., Van Der Kraak, G., Farrel, A.P., Brauner, C.J. (Eds.), Fish Physiology: Fish Neuroendocrinology. Academic Press, London, pp. 3-74.

Cerdá-Reverter, J.M., Haitina, T., Schiöth, H.B., Peter, R.E., 2005. Gene Structure of the Goldfish Agouti-Signaling Protein: A Putative Role in the Dorsal-Ventral Pigment Pattern of Fish. Endocrinology 146, 1597-1610.

Cerdá-Reverter, J.M., Ling, M.K., Schiöth, H.B., Peter, R.E., 2003a. Molecular cloning, characterization and brain mapping of the melanocortin 5 receptor in the goldfish. J. Neurochem. 87, 1354-1367.

Cerdá-Reverter, J.M., Ringholm, A., Schiöth, H.B., Peter, R.E., 2003b. Molecular cloning, pharmacological characterization, and brain mapping of the melanocortin 4 receptor in the goldfish: involvement in the control of food intake. Endocrinology $144,2336-2349$.

Chandramohan, B., Renieri, C., La Manna, V., La Terza, A., 2013. The alpaca agouti gene: genomic locus, transcripts and causative mutations of eumelanic and pheomelanic coat color. Gene 521, 303-310.

Cone, R.D., 2006. Studies on the physiological functions of the melanocortin system. Endocr. Rev. 27, 736-749.

Cone, R.D., Lu, D., Koppula, S., Vage, D.I., Klungland, H., Boston, B., Chen, W., Orth, D.N., Pouton, C., Kesterson, R.A., 1996. The melanocortin receptors:agonists, antagonists, and the hormonal control of pigmentation. Recent Prog. Horm. Res. $51,287-317$. 
Cooray, S.N., Clark, A.J.L., 2011. Melanocortin receptors and their accessory proteins. Mol. Cell. Endocrinol. 331, 215-221.

Darias, M.J., Andree, K.B., Boglino, A., Fernández, I., Estévez, A., Gisbert, E., 2013. Coordinated regulation of chromatophore differentiation and melanogenesis during the ontogeny of skin pigmentation of Solea senegalensis (Kaup, 1858). PLoS One 8, e63005.

Dores, R.M., Lecaude, S., 2005. Trends in the evolution of the proopiomelanocortin gene. Gen. Comp. Endocrinol. 142, 81-93.

Dun, G., Li, X., Cao, H., Zhou, R., Li, L., 2007. Variations of melanocortin receptor 1 (MC1R) gene in three pig breeds. J. Genet. genomics 34, 777-782.

Eberle, A.N., 2000. Proopiomelanocortin and the Melanocortin Peptides, in: Cone, R.D. (Ed.), The Melanocortin Receptors. Humana Press, New Jersey, pp. 3-67.

Eizirik, E., Yuhki, N., Johnson, W.E., Menotti-Raymond, M., Hannah, S.S., O’Brien, S.J., 2003. Molecular genetics and evolution of melanism in the cat family. Curr. Biol. 13, 448-453.

Ellis, H.I., 1980. Metabolism and Solar Radiation in Dark and White Herons in Hot Climates. Physiol. Zool. 53, 358-372.

Eom, D.S., Bain, E.J., Patterson, L.B., Grout, M.E., Parichy, D.M., 2015. Long-distance communication by specialized cellular projections during pigment pattern development and evolution. Elife 4, e12401.

Fontanesi, L., Rustempašić, a., Brka, M., Russo, V., 2012. Analysis of polymorphisms in the agouti signalling protein (ASIP) and melanocortin 1 receptor (MC1R) genes 
and association with coat colours in two Pramenka sheep types. Small Rumin. Res. 105, 89-96.

Forlano, P.M., Cone, R.D., 2007. Conserved Neurochemical Pathways Involved in Hypothalamic Control of Energy Homeostasis. J. Comp. Neurol. 505, 235-248.

Frohnhöfer, H.G., Krauss, J., Maischein, H.-M., Nüsslein-Volhard, C., 2013. Iridophores and their interactions with other chromatophores are required for stripe formation in zebrafish. Development 140, 2997-3007.

Fujii, R., 1993. Coloration and Chromatophores, in: Evans, D. (Ed.), The Physiology of Fishes. FL CRC Press, Boca Raton, pp. 535-562.

Fujii, R., 2000. The Regulation of Motile Activity in Fish Chromatophores. Pigment Cell Res. 13, 300-319.

Fujii, R., Miyashita, Y., 1982. Receptor Mechanisms in Fish Chromatophores - V. MSH Disperses Melanosomes in Both Dermal and Epidermal Melanophores of a Catfish (Parasilurus asotus). Comp. Biochem. Physiol. 71C, 1-6.

Galván, I., Solano, F., 2016. Bird Integumentary Melanins: Biosynthesis, Forms, Function and Evolution Int. J. Mol. Sci. 17(4), 520; doi:10.3390/ijms17040520

García-Borrón, J.C., Sánchez-Laorden, B.L., Jiménez-Cervantes, C., 2005. Melanocortin-1 receptor structure and functional regulation. Pigment Cell Res. 18, $393-410$.

Gilham, I.D., Baker, B.I., 1984. Evidence for the participation of a melaninconcentrating hormone in physiological colour change in the eel. J. Endocrinol. $102,237-243$. 
Goda, M., Fujii, R., 1995. Blue Chromatophores in Two Species of Callionymid Fish. Zoolog. Sci. 12, 811-813.

Gross, J.B., Borowsky, R., Tabin, C.J., 2009. A novel role for Mc1r in the parallel evolution of depigmentation in independent populations of the cavefish Astyanax mexicanus. PLoS Genet. 5, e1000326.

Guillot, R., Ceinos, R.M., Cal, R., Rotllant, J., Cerdá-Reverter, J.M., 2012. Transient ectopic overexpression of agouti-signalling protein 1 (Asip1) induces pigment anomalies in flatfish. PLoS One 7, e48526.

Hearing, V.J., 2000. The melanosome: the perfect model for cellular responses to the environment. Pigment cell Res. 13 Suppl 8, 23-34.

Hernandez-Rauda, R., Aldegunde, M., 2002. Changes in dopamine, norepinephrine and serotonin levels in the pituitary, telencephalon and hypothalamus during gonadal development of male Lutjanus argentiventris (Teleostei). Mar. Biol. 141, 209-216.

Higdon, C.W., Mitra, R.D., Johnson, S.L., 2013. Gene expression analysis of zebrafish melanocytes, iridophores, and retinal pigmented epithelium reveals indicators of biological function and developmental origin. PLoS One 8, e67801.

Hoekstra, H.E., 2006. Genetics, development and evolution of adaptive pigmentation in vertebrates. Heredity (Edinb). 97, 222-234.

Iga, T., Matsuno, A., 1986. Motile iridophores of a freshwater goby , Odontobutis obscura. Cell Tissue Res. 244, 165-171.

Kawauchi, H., Kawazoe, I., Tsubokawa, M., Kishida, M., Baker, B.I., 1983. Characterization of melanin-concentrating hormone in chum salmon pituitaries. 
Nature 305, 321-323.

Klovins, J., Haitina, T., Fridmanis, D., Kilianova, Z., Kapa, I., Fredriksson, R., GalloPayet, N., Schiöth, H.B., 2004a. The melanocortin system in Fugu: determination of POMC/AGRP/MCR gene repertoire and synteny, as well as pharmacology and anatomical distribution of the MCRs. Mol. Biol. Evol. 21, 563-579.

Klovins, J., Haitina, T., Ringholm, A., Löwgren, M., Fridmanis, D., Slaidina, M., Stier, S., Schiöth, H.B., 2004b. Cloning of two melanocortin (MC) receptors in spiny dogfish: MC3 receptor in cartilaginous fish shows high affinity to ACTH-derived peptides while it has lower preference to gamma-MSH. Eur. J. Biochem. 271, $4320-4331$.

Kobayashi, T., Vieira, W.D., Potterf, B., Sakai, C., Imokawa, G., Hearing, V.J., 1995. Modulation of melanogenic protein expression during the switch from eu- to pheomelanogenesis. J. Cell Sci. 108, 2301-2309.

Kobayashi, Y., Chiba, H., Mizusawa, K., Suzuki, N., Cerdá-Reverter, J.M., Takahashi, A., 2011a. Pigment-dispersing activities and cortisol-releasing activities of melanocortins and their receptors in xanthophores and head kidneys of the goldfish Carassius auratus. Gen. Comp. Endocrinol. 173, 438-446.

Kobayashi, Y., Chiba, H., Yamanome, T., Schiöth, H.B., Takahashi, A., $2011 b$. Melanocortin receptor subtypes in interrenal cells and corticotropic activity of $\alpha$ melanocyte-stimulating hormones in barfin flounder, Verasper moseri. Gen. Comp. Endocrinol. 170, 558-568.

Kobayashi, Y., Hamamoto, A., Takahashi, A., Saito, Y., 2016. Dimerization of melanocortin receptor 1 (MC1R) and MC5R creates a ligand-dependent signal 
modulation: Potential participation in physiological color change in the flounder. Gen. Comp. Endocrinol. 230-231, 103-109.

Kobayashi, Y., Mizusawa, K., Chiba, H., Tagawa, M., Takahashi, A., 2012a. Further evidence on acetylation-induced inhibition of the pigment-dispersing activity of $\alpha$ melanocyte-stimulating hormone. Gen. Comp. Endocrinol. 176, 9-17.

Kobayashi, Y., Mizusawa, K., Saito, Y., Takahashi, A., 2012b. Melanocortin systems on pigment dispersion in fish chromatophores. Front. Endocrinol. (Lausanne). 3, 9.

Kobayashi, Y., Mizusawa, K., Yamanome, T., Chiba, H., Takahashi, A., 2009. Possible paracrine function of alpha-melanocyte-stimulating hormone and inhibition of its melanin-dispersing activity by N-terminal acetylation in the skin of the barfin flounder, Verasper moseri. Gen. Comp. Endocrinol. 161, 419-424.

Kobayashi, Y., Tsuchiya, K., Yamanome, T., Schiöth, H.B., Takahashi, A., 2010. Differential expressions of melanocortin receptor subtypes in melanophores and xanthophores of barfin flounder. Gen. Comp. Endocrinol. 168, 133-142.

Kodric-Brown, A., Nicoletto, P., 2001. Female choice in the guppy ( Poecilia reticulata): the interaction between male color and display. Behav. Ecol. Sociobiol. $50,346-351$.

Kottler, V.A., Künstner, A., Schartl, M., 2015. Pheomelanin in fish? Pigment Cell Melanoma Res. 28, 355-356.

Kreiner, P.W., Gold, C.J., Keirns, J.J., Brock, W.A., Bitensky, M.W., 1973. MSH-Sensitive Adenyl Cyclase in the Cloudman Melanoma 591, 583-591.

Kumar, A., Bhandari, A., Sinha, R., Goyal, P., Grapputo, A., 2011. Spliceosomal intron insertions in genome compacted ray-finned fishes as evident from phylogeny of 
MC receptors, also supported by a few other GPCRs. PLoS One 6, e22046.

Kurokawa, T., Murashita, K., Uji, S., 2006. Characterization and tissue distribution of multiple agouti-family genes in pufferfish, Takifugu rubripes. Peptides 27, 31653175 .

Li, Y., Li, G., Wang, H., Du, J., Yan, J., 2013. Analysis of a Gene Regulatory Cascade Mediating Circadian Rhythm in Zebrafish. PLoS Comput. Biol. 9, e1002940.

Liang, L., Reinick, C., Angleson, J.K., Dores, R.M., 2013. Evolution of melanocortin receptors in cartilaginous fish: Melanocortin receptors and the stress axis in elasmobranches. Gen. Comp. Endocrinol. 181, 4-9.

Ling, M.K., Lagerström, M.C., Fredriksson, R., Okimoto, R., Mundy, N.I., Takeuchi, S., Schiöth, H.B., 2003. Association of feather colour with constitutively active melanocortin 1 receptors in chicken. Eur. J. Biochem. 270, 1441-1449.

Lister, J. a, Robertson, C.P., Lepage, T., Johnson, S.L., Raible, D.W., 1999. Nacre Encodes a Zebrafish Microphthalmia-Related Protein That Regulates Neural-CrestDerived Pigment Cell Fate. Development 126, 3757-3767.

Logan, D.W., Burn, S.F., Jackson, I.J., 2006. Regulation of pigmentation in zebrafish melanophores. Pigment Cell Res. 19, 206-213.

Lu, D., Willard, D., Patel, I.R., Kadwell, S., Overton, L., Kost, T., Luther, M., Chen, W., Woychik, R.P., Wilkison, W.O., 1994. Agouti protein is an antagonist of the melanocyte-stimulating-hormone receptor. Nature 371, 799-802.

Maan, M.E., Sefc, K.M., 2013. Colour variation in cichlid fish: developmental mechanisms, selective pressures and evolutionary consequences. Semin. Cell Dev. 
Biol. 24, 516-528.

Maderspacher, F., 2003. Formation of the adult pigment pattern in zebrafish requires leopard and obelix dependent cell interactions. Development 130, 3447-3457.

Manceau, M., Domingues, V.S., Mallarino, R., Hoekstra, H.E., 2011. The developmental role of Agouti in color pattern evolution. Science 331, 1062-1065.

Matsumoto, J., Watanabe, Y., Obika, M., Hadley, M.E., 1977. Mechanisms Controlling Pigment Movements within Swordtail (Xiphophorus helleri) Erythrophores in Primary Cell Culture. Comp. Biochem. Physiol. 61, 509-517.

Metz, J.R., Peters, J.J.M., Flik, G., 2006. Molecular biology and physiology of the melanocortin system in fish: a review. Gen. Comp. Endocrinol. 148, 150-162.

Millar, S.E., Miller, M.W., Stevens, M.E., Barsh, G.S., 1995. Expression and transgenic studies of the mouse agouti gene provide insight into the mechanisms by which mammalian coat color patterns are generated. Development 121, 3223-3232.

Miller, M.W., Duhl, D.M., Vrieling, H., Cordes, S.P., Ollmann, M.M., Winkes, B.M., Barsh, G.S., 1993. Cloning of the mouse agouti gene predicts a secreted protein ubiquitously expressed in mice carrying the lethal yellow mutation. Genes Dev. 7, 454-467.

Mizusawa, K., Kobayashi, Y., Yamanome, T., Saito, Y., Takahashi, A., 2013. Interrelation between melanocyte-stimulating hormone and melanin-concentrating hormone in physiological body color change: roles emerging from barfin flounder Verasper moseri. Gen. Comp. Endocrinol. 181, 229-234.

Murashita, K., Kurokawa, T., Ebbesson, L.O.E., Stefansson, S.O., Rønnestad, I., 2009. 
Characterization, tissue distribution, and regulation of agouti-related protein (AgRP), cocaine- and amphetamine-regulated transcript (CART) and neuropeptide Y (NPY) in Atlantic salmon (Salmo salar). Gen. Comp. Endocrinol. 162, 160-171.

Nadeau, N.J., Minvielle, F., Mundy, N.I., 2006. Association of a Glu92Lys substitution in MC1R with extended brown in Japanese quail (Coturnix japonica). Anim. Genet. 37, 287-289.

Nakanishi, S., Inoue, A., Kita, T., Nakamura, M., Chang, A.C., Cohen, S.N., Numa, S., 1979. Nucleotide sequence of cloned cDNA for bovine corticotropin- $\beta$-lipotropin precursor. Nature 278, 423-427.

Nelson, J.S., 2006. Fishes of the world, 4 th ed, Bulletin of Marine Science. John Wiley \& Sons, Hoboken, New Jersey.

Newton, J., Wilkie, A., He, L., Jordan, S., Metallinos, D., Holmes, N., Jackson, I.J., Barsh, G., 2000. Melanocortin 1 receptor variation in the domestic dog. Mamm. Genome 11, 24-30.

Norris, B.J., Whan, V. a, 2008. A gene duplication affecting expression of the ovine ASIP gene is responsible for white and black sheep. Genome Res. 18, 1282-1293.

Ollmann, M.M., Barsh, G.S., 1999. Down-regulation of Melanocortin Receptor Signaling Mediated by the Amino Terminus of Agouti Protein in Xenopus Melanophores. J. Biol. Chem. 274, 15837-15846.

Ollmann, M.M., Lamoreux, M.L., Wilson, B.D., Barsh, G.S., 1998. Interaction of Agouti protein with the melanocortin 1 receptor in vitro and in vivo. Genes Dev. $12,316-330$. 
Ollmann, M.M., Wilson, B.D., Yang, Y.K., Kerns, J.A., Chen, Y., Gantz, I., Barsh, G.S., 1997. Antagonism of Central Melanocortin Receptors in Vitro and in Vivo by Agouti-Related Protein. Science 278, 135-138.

Patel, M.P., Fabersunne, C.S.C., Yang, Y., Kaelin, C.B., Barsh, G.S., Millhauser, G.L., 2010. Loop Swapped Chimeras of the Agouti-related Protein (AgRP) and the Agouti Signaling Protein (ASIP) Identify contacts required for Melanocortin 1 Receptor (MC1R) Selectivity and Antagonism. J. Mol. Biol. 404, 45-55.

Patterson, L.B., Parichy, D.M., 2013. Interactions with iridophores and the tissue environment required for patterning melanophores and xanthophores during zebrafish adult pigment stripe formation. PLoS Genet. 9, e1003561.

Protas, M.E., Patel, N.H., 2008. Evolution of coloration patterns. Annu. Rev. Cell Dev. Biol. 24, 425-446.

Ringholm, A., Fredriksson, R., Poliakova, N., Yan, Y.-L., Postlethwait, J.H., Larhammar, D., Schiöth, H.B., 2002. One melanocortin 4 and two melanocortin 5 receptors from zebrafish show remarkable conservation in structure and pharmacology. J. Neurochem. 82, 6-18.

Robbins, L.S., Nadeau, J.H., Johnson, K.R., Kelly, M.A., Roselly-Rehfuss, L., Baack, E., Mountjoy, K.G., Cone, R.D., 1993. Pigmentation phenotypes of variant extension locus alleles result from point mutation that alter MSH receptor function. Cell 72, 827-834.

Roesler, W.J., Park, E.A., McFie, P.J., 1998. Characterization of CCAAT/enhancerbinding protein alpha as a cyclic AMP-responsive nuclear regulator. J Biol Chem $273,14950-14957$. 
Rotllant, J., Tort, L., Montero, D., Pavlidis, M., Martinez, M., Wendelaar Bonga, S.E., Balm, P.H.M., 2003. Background colour influence on the stress response in cultured red porgy Pagrus pagrus. Aquaculture 223, 129-139.

Rozdzial, M.M., Haimo, L.T., 1986. Bidirectional pigment granule movements of melanophores are regulated by protein phosphorylation and dephosphorylation. Cell 47, 1061-1070.

Rudh, A., Qvarnström, A., 2013. Adaptive colouration in amphibians. Semin. Cell Dev. Biol. 24, 553-561.

Sánchez, E., Rubio, V.C., Cerdá-Reverter, J.M., 2009a. Characterization of the sea bass melanocortin 5 receptor: a putative role in hepatic lipid metabolism. J. Exp. Biol. 212, 3901-3910.

Sánchez, E., Rubio, V.C., Cerdá-Reverter, J.M., 2010. Molecular and pharmacological characterization of the melanocortin type 1 receptor in the sea bass. Gen. Comp. Endocrinol. 165, 163-169.

Sánchez, E., Rubio, V.C., Thompson, D., Metz, J., Flik, G., Millhauser, G.L., CerdáReverter, J.M., 2009b. Phosphodiesterase inhibitor-dependent inverse agonism of agouti-related protein on melanocortin 4 receptor in sea bass (Dicentrarchus labrax). Am. J. Physiol. Regul. Integr. Comp. Physiol. 296, R1293-R1306.

Schartl, M., Larue, L., Goda, M., Bosenberg, M.W., Hashimoto, H., Kelsh, R.N., 2015. What is a vertebrate pigment cell? Pigment Cell Melanoma Res. 29, 1-8.

Schiöth, H.B., Haitina, T., Ling, M.K., Ringholm, A., Fredriksson, R., Cerdá-Reverter, J.M., Klovins, J., 2005. Evolutionary conservation of the structural, pharmacological, and genomic characteristics of the melanocortin receptor 
subtypes. Peptides 26, 1886-1900.

Schioth, H.B., Vastermark, A., Cone, R.D., 2011. Reply to Braasch and Postlethwait: Evolutionary origin of the teleost A2 agouti genes (agouti signaling protein 2 and agouti related protein 2) remains unclear. Proc. Natl. Acad. Sci. 108, 49-50.

Selz, Y., Braasch, I., Hoffmann, C., Schmidt, C., Schultheis, C., Schartl, M., Volff, J.N., 2007. Evolution of melanocortin receptors in teleost fish: the melanocortin type 1 receptor. Gene 401, 114-122.

Singh, A.P., Schach, U., Nüsslein-Volhard, C., 2014. Proliferation, dispersal and patterned aggregation of iridophores in the skin prefigure striped colouration of zebrafish. Nat. Cell Biol. 16, 607-614.

Siracusa, L.D., 1994. The agouti gene: turned on to yellow. Trends Genet. 10, 423-428.

Song, Y., Cone, R.D., 2007. Creation of a genetic model of obesity in a teleost. FASEB J. 21, 2042-2049.

Sugimoto, M., 2002. Morphological color changes in fish: regulation of pigment cell density and morphology. Microsc. Res. Tech. 58, 496-503.

Sugimoto, M., Nagamori, H., Yasui, H., Oshima, N., 1997. Regulation of melanophore responsiveness in the background-adapted medaka, Oryzias latipes: change in the intracellular signaling system. Comp. Biochem. Physiol. C. Pharmacol. Toxicol. Endocrinol. 117, 259-265.

Sugimoto, M., Yuki, M., Miyakoshi, T., Maruko, K., 2005. The Influence of LongTerm Chromatic Adaptation on Pigment Cells and Striped Pigment Patterns in the Skin of the Zebrafish, Danio rerio. J. Exp. Zool. 303A, 430-440. 
Takahashi, A., Mizusawa, K., 2013. Posttranslational modifications of proopiomelanocortin in vertebrates and their biological significance. Front. Endocrinol. (Lausanne). 4, 143.

Takahashi, A., Mizusawa, K., Amano, M., 2014. Multifunctional Roles of MelanocyteStimulating Hormone and Melanin-Concentrating Hormone in Fish: Evolution from Classical Body Color Change. Aqua-BioScience Monogr. 7, 1-46.

Takahashi, G., Kondo, S., 2008. Melanophores in the stripes of adult zebrafish do not have the nature to gather, but disperse when they have the space to move. Pigment Cell Melanoma Res. 21, 677-686.

To, T.T., Hahner, S., Nica, G., Rohr, K.B., Hammerschmidt, M., Winkler, C., Allolio, B., 2007. Pituitary-interrenal interaction in zebrafish interrenal organ development. Mol. Endocrinol. 21, 472-485.

Valverde, P., Healy, E., Jackson, I., Rees, J.L., Thody, A.J., 1995. Variants of the melanocyte-stimulating hormone receptor gene are associated with red hair and fair skin in humans. Nat. Genet. 11, 328-330.

van der Salm, A.L., Metz, J.R., Bonga, S.E.W., Flik, G., 2005. Alpha-MSH, the melanocortin-1 receptor and background adaptation in the Mozambique tilapia, Oreochromis mossambicus. Gen. Comp. Endocrinol. 144, 140-149.

van Eys, G.J., Peters, P.T., 1981. Evidence for a direct role of alpha-MSH in morphological background adaptation of the skin in Sarotherodon mossambicus. Cell Tissue Res. 217, 361-372.

Västermark, Å., Krishnan, A., Houle, M.E., Fredriksson, R., Cerdá-Reverter, J.M., Schiöth, H.B., 2012. Identification of distant Agouti-like sequences and re- 
evaluation of the evolutionary history of the agouti-related peptide (AgRP). PLoS One 7, e40982.

Vrieling, H., Duhl, D.M., Millar, S.E., Miller, K. a, Barsh, G.S., 1994. Differences in dorsal and ventral pigmentation result from regional expression of the mouse agouti gene. Proc. Natl. Acad. Sci. U. S. A. 91, 5667-5671.

Wendelaar-Bonga, S.E., Balm, P.H.M., Lamers, A.E., 1994. The Involvement of Acth and Msh in the Stress Response in Teleost Fish. Netherlands J. Zool. 45, 103-106.

Wilkinson, C.W., 2006. Roles of acetylation and other post-translational modifications in melanocortin function and interactions with endorphins. Peptides 27, 453-471.

Yamanome, T., Chiba, H., Takahashi, A., 2007. Melanocyte-stimulating hormone facilitates hypermelanosis on the non-eyed side of the barfin flounder, a pleuronectiform fish. Aquaculture 270, 505-511.

Zhang, C., Song, Y., Thompson, D. a, Madonna, M. a, Millhauser, G.L., Toro, S., Varga, Z., Westerfield, M., Gamse, J., Chen, W., Cone, R.D., 2010. Pineal-specific agouti protein regulates teleost background adaptation. Proc. Natl. Acad. Sci. U. S. A. 107, 20164-20171. 


\section{LEGENDS}

Fig. 1. The melanocortin system and fish pigmentation. Schematic drawing of the hypothetical regulatory control model of pigmentation through different melanocortin system components in fish chromatophores. (A) Melanophores, (B) xanthophores, and (C) iridophores. ( $\uparrow)$, stimulation; ( $($ ), inhibition; (?, dotted line), unknown.

Fig. 2. Scheme of POMC posttranslational modifications. POMC is the precursor of several peptide hormones. POMC is modified differently in corticotrope cells and melanotrope cells. The scheme summarizes the tissue-specific POMC-derived products in fish. ACTH is the major product in corticotrope cells, but other products may be found, depending on the species. In melanotrope cells, some of the many different products are class-specific. An asterisk $(*)$ indicates a region in the POMC sequence that is lost in teleosts. Two asterisks (**) indicate a specific region that appears only in chondrichthyans (cartilaginous fishes such as sharks and rays).

Fig. 3. Differential dorso-ventral asip/asip1 gene expression. asip/asipl is differentially expressed in dorsal pigmented skin (black bar) and ventral non-pigmented skin (white bar) in turbot (Scophthalmus maximus), zebrafish (Danio rerio), and spotted gar (Lepisosteus oculatus). asiplasipl gene expression was quantified by qRT-PCR. Data are the mean \pm SEM [Standard error of the mean]. The numerical data were compared by paired Student t-tests. Asterisks indicate significant differences $(\mathrm{P}<0.05)$ between dorsal and ventral asip1 expression. Scale bars: $1 \mathrm{~cm}$.

Fig. 4. Disruption of the dorso-ventral countershading pattern in transgenic zebrafish overexpressing asip1. Lateral view of adult pigment pattern of wild type (WT) and transgenic agouti zebrafish [asip1-Tg; line $\operatorname{Tg}(X l a . E e f 1 a 1: C a u . A s i p 1) i i m 05 ;$ Ceinos et al., 2015)] (A) Wildtype fish have a pattern with dark stripes and light interstripes. (B) Asip1-Tg fish show a dramatic reduction in melanophore numbers in the dorsal regions. Scale bar: $1 \mathrm{~cm}$. 


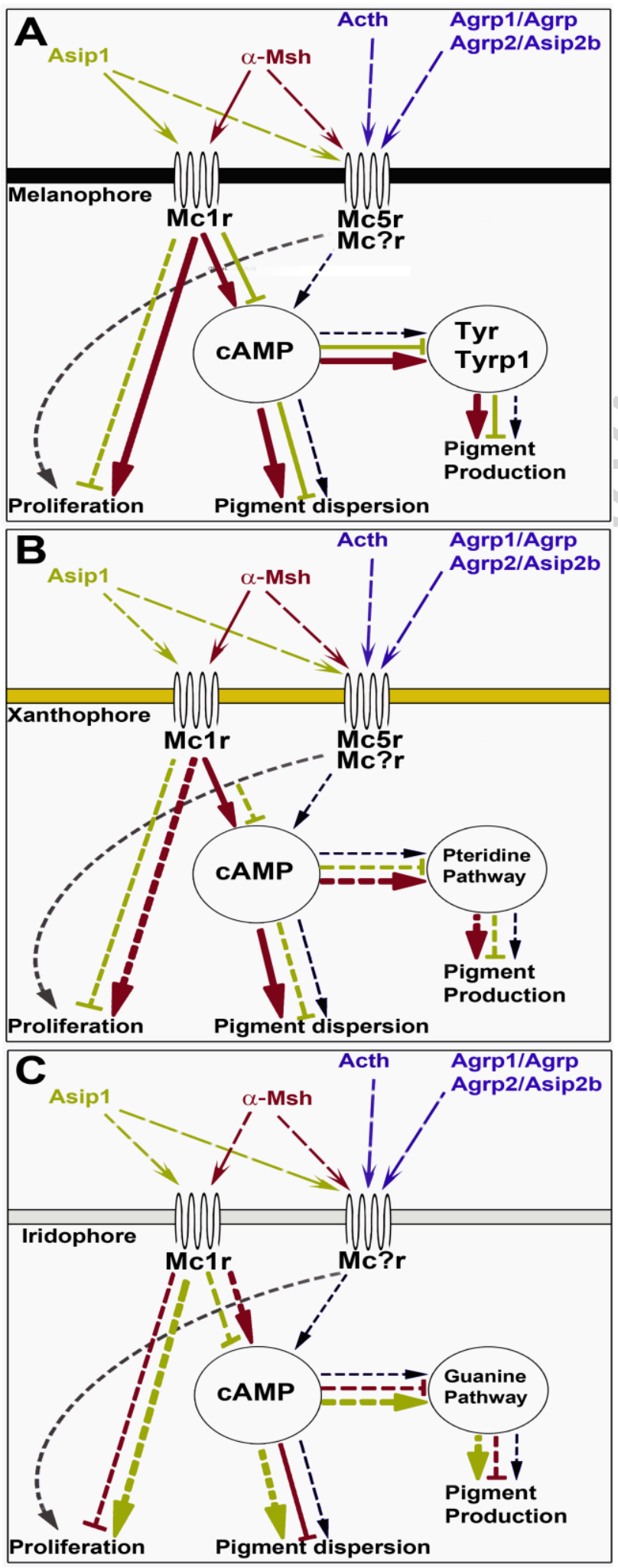

Figure 1 


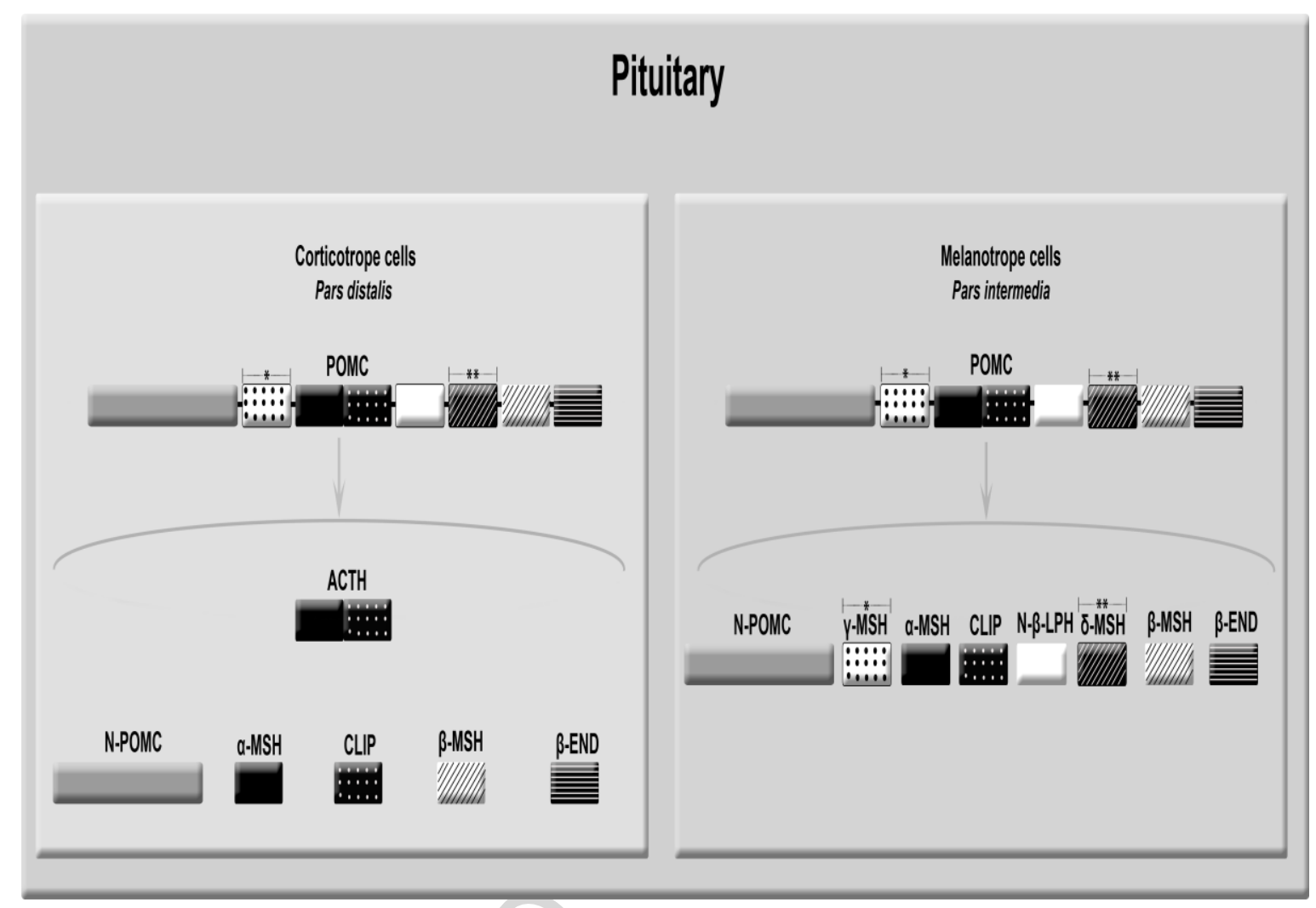

Figure 2 


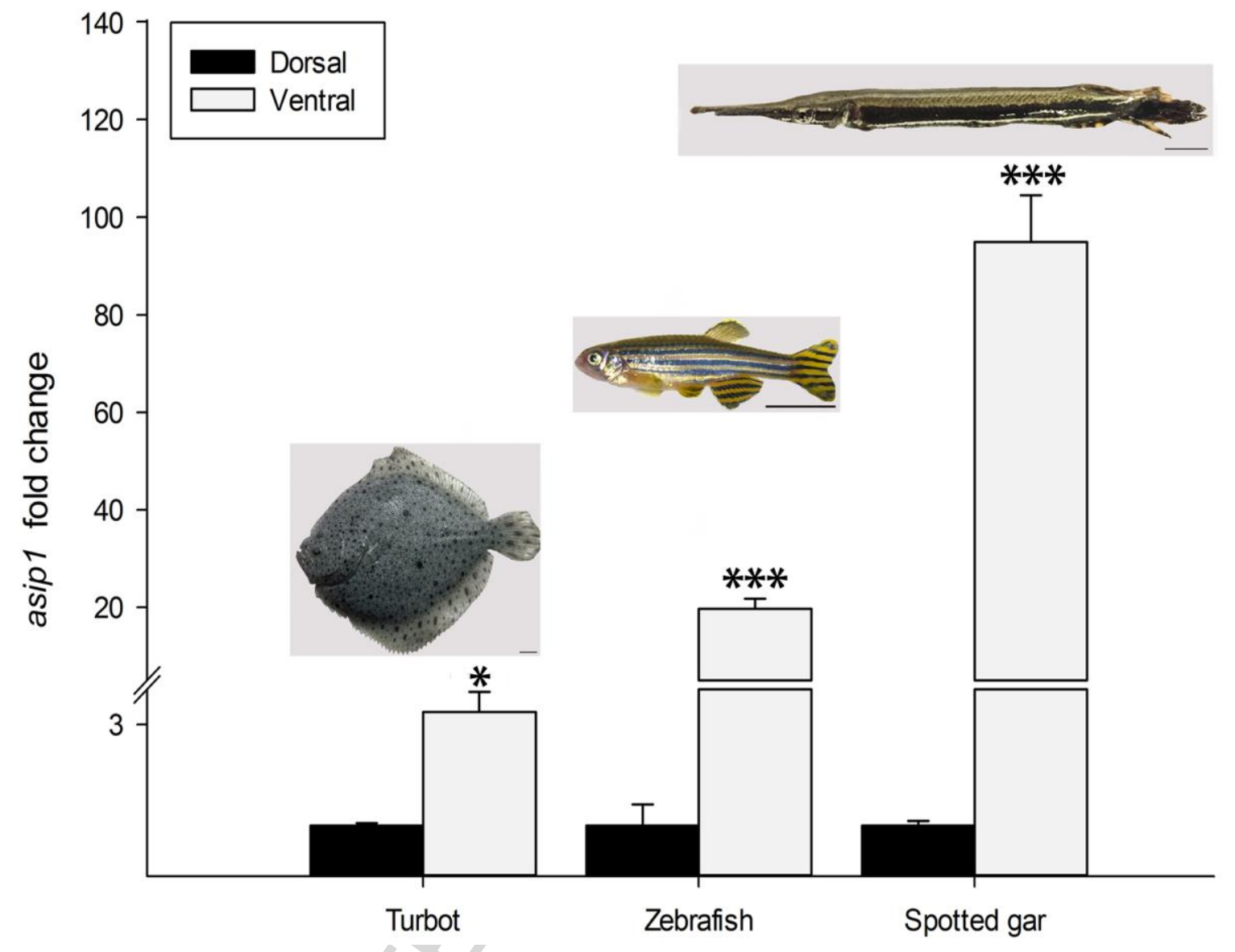

Figure 3 


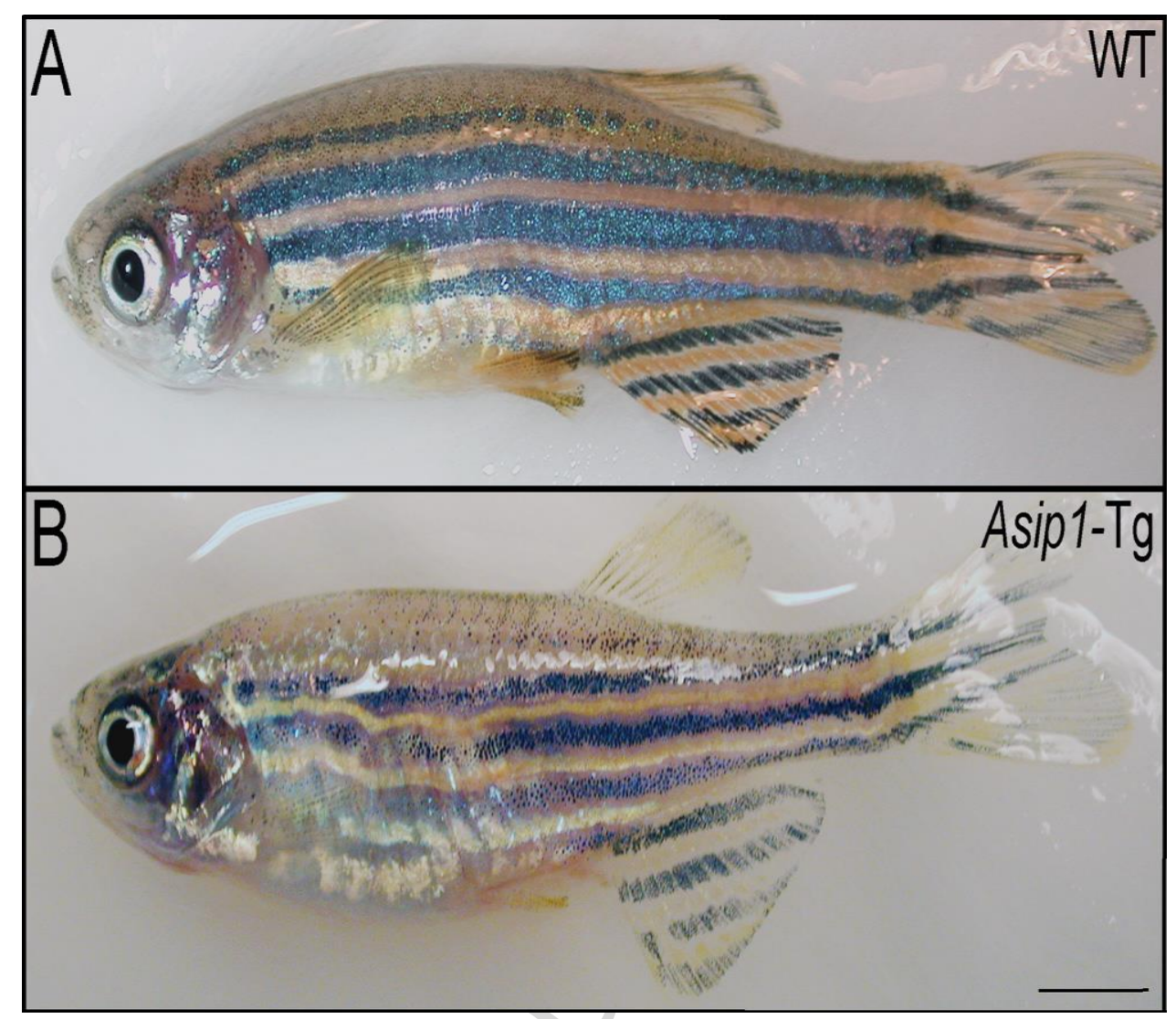

Figure 4 